\title{
The Role of Anaerobic Digestion in Achieving Soil Conservation and Sustainable Agricultural Development in the UK
}

\author{
Franklin I. Duruiheoma (Corresponding author) \\ Department of Biological Sciences, University of Chester, England \\ E-mail: f.duruiheoma@chester.ac.uk \\ Cynthia V. Burek \\ Department of Biological Sciences, University of Chester, England
}

Graham Bonwick

The Institute of Food Science and Innovation, University of Chester, England

Roy Alexander

Department of Geography and International Development, University of Chester,

England

Received: May 1, 2015 Accepted: June 4, 2015 Published: November 23, 2015

doi:10.5296/jee.v6i2.7522ＵRL: http://dx.doi.org/10.5296/jee.v6i2.7522

\begin{abstract}
Anaerobic digestion represents one form of renewable energy technology but has many wider benefits. This paper reviews the processes involved in anaerobic digestion, the type of systems in place and the use of digestate to improve soil quality. A case is made for the technology in the UK in the context of soil conservation and sustainable agricultural production. Its broader contribution to sustainable development in the United Kingdom is also considered. Low levels of awareness of the benefits of anaerobic digestion, poor access to funds, inadequate incentives, an unfavourable legislative and policy framework for the
\end{abstract}




\section{Macrothink}

Journal of Environment and Ecology

ISSN 2157-6092

2015, Vol. 6, No. 2

technology, limited application of digestate for agricultural purposes and the need for further research on digestate use are identified as key factors hindering uptake of the technology. Anaerobic digestion is presented as a technology that can support soil conservation and sustainable agricultural development while also generating both energy and income, enhancing waste and nutrient recycling and promoting environmental protection.

Keywords: public awareness, conservation, food security, population growth, soil degradation, sustainability 


\section{Introduction}

The threat to natural resources from population growth, environmental pollution and climate change has made the concept of sustainable development a popular one. The concept has heralded most environmental management programmes and policies in a global context for more than two decades. The concept marked an end to traditional ways of resource use in development, where considerations for future generations' needs were not considered (Golusin et al. 2011). Rogers et al. (2008) stated that the concept of 'sustainability' which has now become a slogan in natural resource management, serves as the link between the environment and development. The report World Commission on Environment and Development (WCED), also known as the Brundtland Report, of 1987 gave the definition of sustainable development as that form of development that meets the need of present generation without compromising the ability of future generations to meet their own needs. Like most concepts and theories associated with nature conservation and environmental management, sustainable development is still a pursuit in most part of the world due to different interpretations of the concept.

Agricultural wastes especially livestock farms, have high potential to cause environmental pollution. Anaerobic Digestion (AD) is a technology designed to minimize the risk of environmental pollution from agricultural processes and products, and in addition generates revenue from energy production and organic fertilizer as by-product. Wilkinson (2011) described $\mathrm{AD}$ as that technology which plays a steadily growing role in renewable energy practices in many countries. AD technologies are not new in any sense in most parts of the World, and have been in existence for over a century in the UK mainly for sewage sludge treatment (POST 2011). Similar cases of AD technology utilization have been reported in other parts of Europe, America and Australia. In developing nations, it has been stated that the presence of $\mathrm{AD}$ technologies is linked to strategies for sustainable development with the need to conserve natural resources and achieve regional development (Lei and Haight 2007). Certain rural communities in Asia make use of small scale AD plants for the digestion of 'night soil' to provide biogas for cooking and lighting domestic households (Wilkinson 2011). Night soil here refers to human faecal material which is harmful when applied directly without treatment as manure in farmlands or used for other agricultural purpose as used historically in some parts of Asia (Bo et al. 1993). There is growing interest in the various types of raw materials that can be processed by AD technology and this potential stresses the various benefits and prospects for $\mathrm{AD}$ technologies in the $21^{\text {st }}$ century, which include:

a) Renewable energy production;

b) Waste recycling and environmental protection; and

c) Nutrient recycling.

In terms of raw material inputs, digestible organic materials are not lacking when the numbers of farms across the UK are taken into account, however the installation of AD plants is faced with a number of challenging factors. These factors serve as both drivers and barriers to the enhancement of $\mathrm{AD}$ technologies. Wilkinson (2011) classified these factors into four 
different categories namely: geopolitical factors, nature of farming systems, social factors and economic factors. Each of these plays a significant role on an individual basis and collectively they have affected the establishment of $\mathrm{AD}$ technologies over the years. Geopolitical, social and economic factors were also identified as exerting their effects across local, regional and national boundaries.

Soils are a very important component of the environment and their potential contribution to sustainability outside agricultural uses are yet to be fully recognised. Soils are complex in nature and are closely related to other elements of the environment, biotic and abiotic, providing direct and indirect services to the environment and Man. The most important service provided by soil is for agricultural purposes. Soils occur in the uppermost layer of the Earth's crust and so affect the nature of landforms, wildlife and vegetation. The capacity of the soil to function continuously as an important part of the ecosystem, maintain biological productivity, enhance air and water quality, and sustain the health of plant, animal and human is known as soil quality (Schloter et al. 2003), while soil productivity refers to the capacity of soil under a specific management system to produce a particular yield of crops (Blanco-Canqui and Lal 2009). A combination of human activities and natural events like intensive agriculture, construction, pollution, erosion, landslides and flooding reduce the quality of soils, and this reduction in soil quality according to McOlivers (1984) implies a decline in soil productivity. The consequences of a decline in soil productivity which affects its ability to deliver ecosystem services and functions are not fully appreciated, as soils are still subject to various levels of degradation across the world. The conservation of soils in view of rising world population, climate change and food security issues should be a matter of great concern at local, national and international level. In addition to natural and Man-made factors causing soil degradation, population growth has some direct and indirect effects. The predictions of world population growth and its effects on natural resources as contained in Malthusian theory of population growth have been made manifest in the world today (Satihal et al. 2007). The effects of population growth on the degradation of soils are indirect and are linked to food security concerns, which often require intensified agricultural production and the provision of basic amenities like shelter for Man which reduces available agricultural land. Within these scenarios, the importance of sustainable agriculture which considers economic, environmental and social sustainability is crucial.

This article argues that AD technology will promote the conservation of soils by providing digestate which is a rich organic fertilizer, and support the objectives of sustainable agriculture, thereby promoting sustainable development.

\section{AD Technology and Process}

$\mathrm{AD}$ has been defined as the process by which organic materials are treated biologically by naturally occurring bacteria in the absence of oxygen to produce biogas which is made up of methane $\left(\mathrm{CH}_{4}\right)$ (40-70\%), carbon dioxide $\left(\mathrm{CO}_{2}\right)$ (30-60\%) and other trace gases such as ammonia, hydrogen, hydrogen sulphide and a very useful by-product known as "digestate" in liquid or solid form (Wilkinson 2011).

AD plants can be configured to yield substantial amounts (depending on plant size) of biofuel, 
mainly biogas, and a residual digestate which can serve as a nutrient rich fertilizer (POST 2011). This is illustrated in figure 1 . The environment is generally sealed insulated concrete or steel tanks with some form of agitation, and inside this environment, conditions for anaerobic digestions are created artificially (Mainero 2012).

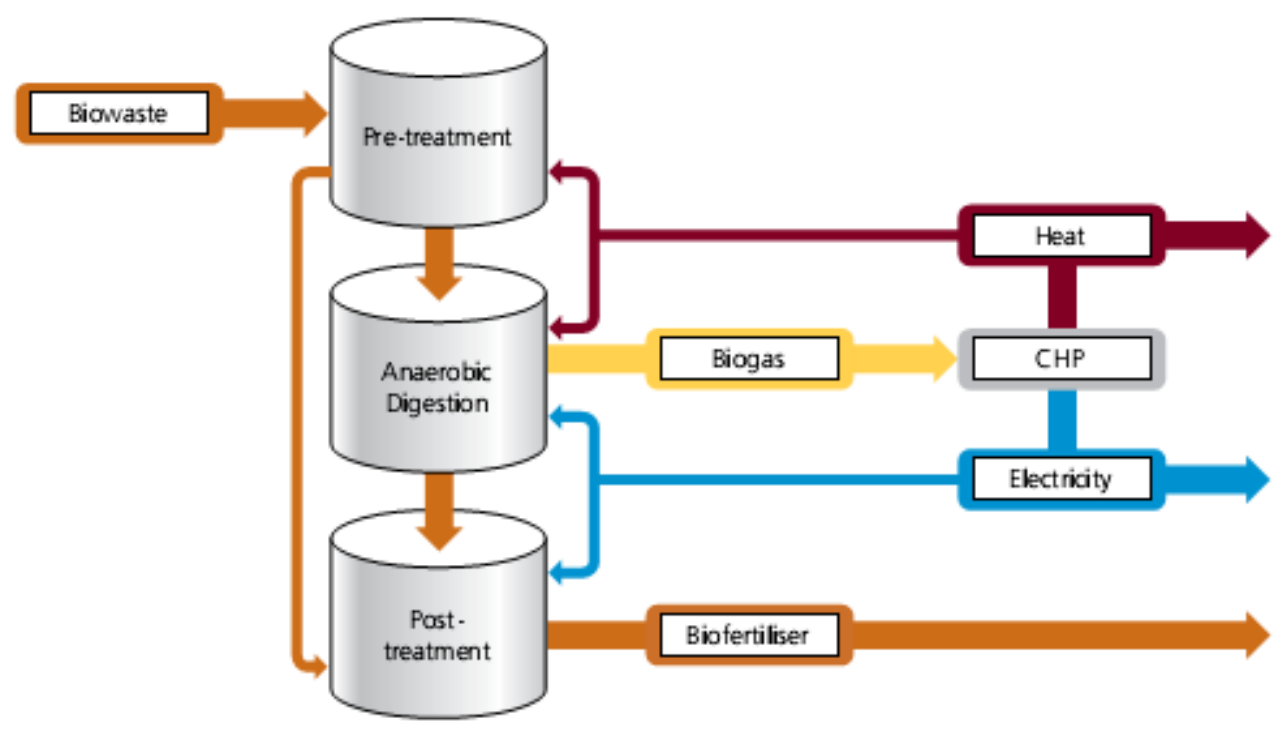

Figure 1. An illustration of a configured AD plant

Source: DEFRA (2011)

It has been argued that an estimated $90 \%$ of the energy produced in anaerobic plants from the degradation of biodegradable inputs is retained in the form of methane, resulting in the production of very little excess sludge (Wood et al. 2013). The output from anaerobic digesters however, is largely a function of the operational conditions and design of the digesters (Lawson 2010; DEFRA 2011; Motte et al. 2013). The various technologies available for AD are: the wet and dry, mesophilic or thermophilic, and single or multistage. In England where most of the AD plants in the UK are sited, the most common types of technology in use are the mesophilic, wet and single style types (DEFRA 2011).

Mesophilic and thermophilic systems- Mesophilic systems are those with bacteria that perform optimally at temperatures between $35-40^{\circ} \mathrm{C}$ and while those with bacteria that perform optimally at temperatures between $55-60^{\circ} \mathrm{C}$ are called thermophilic systems (Lawson 2010; DEFRA 2011; Hollister et al. 2012). As a result of higher temperature requirements, thermophilic systems make use of higher energy inputs, and are therefore more expensive. With the high temperature however, the entire process is faster in thermophilic systems than mesophilic systems (Lawson 2010).

Wet and Dry-wet systems are often mesophilic, with the main component as water, and solid components are generally less than $15 \%$, with a residence time of 60-95days, while dry systems are often thermophilic, with solid components making more than $20 \%$ (and can be up to $45 \%$ ) with a residence time from 9-45 days (Lawson 2010; Lucas et al. 2014). Dry systems 
require less mechanical sorting and the process takes place with materials still in solid form, while the raw materials in wet systems need to be in the form of pulp or have a soup-like consistency to facilitate pumping and stirring (Motte et al. 2013). More so, because of the nature of raw material, dry systems process their materials in batches while wet systems do theirs in a continuous flow manner.

Single and Multistage Systems- Single digester systems are those in which biological reactions take place in individual sealed reactors or holding tanks, while multistage systems comprises of various reactors or holding tanks to optimise the entire reaction (DEFRA 2011). Single systems therefore require lower construction costs.

AD plants have also been classified on the basis of type of operation into on-farm $A D$ and centralised $\mathrm{AD}$ (CAD). On-farm $\mathrm{AD}$ are those with feedstock based on the farm, such as manures, silage and slurries and other by-products such as brewer's grains, while CAD uses wastes that attract gate fees and involves higher costs in terms of the whole project and management in comparison to on-farm plants (Mainero 2012).

\section{Soil Conservation- an Important Issue Globally and in the UK}

It has been reported that only an estimated 22\% (14,900 million hectares) of the land area on Earth is potentially productive (El-Swaify 1994; cited in Morgan 2005; Khanif 2010). This proportion of land (soils per se) provides $97 \%$ of World food, since 3\% comes from water bodies like oceans, rivers and lakes. The rising world population will exert even more pressure on soils (Morgan 2005). Apart from food provision, there is every possibility that development will take up part of this potentially productive land area even as world population rises. The total size of the potentially productive land reported in 1994, may therefore be even less at present time (Khanif 2010). More so, Hannam (1999; cited in Stott et al. [eds.] 2001) stated that global reports show that soils are being used beyond their ecological and physical capacity for agriculture. Concerns about the impact of growing world population on natural resources are not new in any sense, and can be traced as far back as the Malthusian theory of population growth as contained in Malthus' book 'Essay on the principle of population growth' (1798). With regards to depletion of land resource and ensuring food security, various techniques have been employed including, intensive agriculture, development of fast yield and production crops and animal hybrids, land reclamation and use of different forms of fertilizers (Hudson 1995).

Soil conservation refers to the combination of all management and land-use methods that safeguard the soil against depletion or degradation caused by nature and/or humans (Brady and Well 2005). Soil degradation here has been defined as a process that reduces the present and/or the potential capacity of a given soil to produce goods and services (Hannam and Boer 2002; Hannam 2004). Population growth promotes such activities as intensified agriculture, urbanization and industrialization, deforestation, mineral exploration and land filling leading to erosion, acidification and pollution of soil resource (Gordon et al. 1995; cited in Taylor et al. [eds.] 1996). Erosion control remains foremost among soil conservation goals in view of the level of devastation it can cause on-site and off-site and the ensuing financial implications. For instance, it is estimated that soil erosion costs the United States of America over US\$30 
billion annually (Uri and Lewis 1998; cited in Morgan 2005). In the UK, POST (2006) reported that about 2.2 million tonnes of topsoil are lost to erosion each year and $17 \%$ of the UK's arable land shows evidence of erosion.

The significance of soil erosion is highlighted as it has been a focus of research over the years and even now certain scientific journals are specific to the problem. It has even become an independent subject area in universities and research institutes (Boardman et al. 2003). As agriculture becomes intensified to meet the demands of rising populations, important soil properties are lost making them more erodible, hence erosion occurs more easily. The problem of soil erosion is universally recognised as a significant threat to the well-being of Man, and even his existence (Hudson 1995). As such, soil conservation is an important environmental concern and has been part of considerable nature conservation efforts (Hartemink and van Keulen 2005; cited in Ingram and Morris 2007).

Various management techniques have evolved over the years for the conservation of soils, but not all of such techniques aid soil conservation in practice. Ingram (2008) reported that the failure of certain soil management practices to achieve soils conservation is as a result of low level of knowledge in addition to lack of experience in the utilization of new technologies and practices mainly by farmers. The ideal management for soil conservation according to Ingram and Morris (2007) should be based on a number of principles which include:

a) the sustenance of soil structures by maintaining soil organic matter and minimizing the compaction of soil during cultivation;

b) avoidance of overworking and runoff; and

c) maintenance of soil buffering capacity for nutrients by encouraging the effective use of artificial and organic fertilizers.

Espousing these principles in a world where priority is being placed on the enhancement of agricultural production to ensure food security and the looming effects of climate change is however difficult. More often, management practices for soil conservation are more concerned with raising the productivity by means of artificial nutrient replenishment, that is, fertilizer application. This was justified by Khanif (2010) when he stated that since there is a need to secure food for population growth, total arable land is declining and land is being degraded, so the available land productivity has to be maximised and fertiliser application is a reliable and viable option. To what extent does this practice actually conserve soil? After all the conservation of soils is not limited to maintaining fertility but also includes reducing degradation to the barest minimum. Hannam and Boer (2004) recognised the escalating imbalance in food production to be a function of the gap existing between soil degradation and the rate of their revitalisation and called for an in-depth reorientation of the attitude of humans to soils and other natural resources.

Raising awareness of the importance of soils remains a significant step in the conservation of soil (EC 2006), as it is more difficult to conserve what is not really valued (Towers et al. 2005). By raising awareness, soils will become more valued, especially to direct users like farmers who often have little in depth knowledge about their soils as Ingram (2008) stated, 
and the degradation of agricultural soils has been linked to their unsustainable management by farmers (Boardman et al. 2003). Although soil and environmentally-friendly techniques such as integrated farming, reduced tillage, use of light-weight tractors and organic farming do exist their understanding and effective application remains questionable. Once again, it is necessary for farmers and all stakeholders to be fully knowledgeable on the new and safe ways of promoting soil conservation. For example, in the practice of organic farming which practically involve the use of organic fertilizers mainly from organic wastes, a thorough knowledge is required to ensure its efficient use in terms of quality and value (Rowell et al. 2001; cited in Tambone et al. 2010), even as the use of such organic inputs can have both positive and negative effects on the soil (Johansen et al. 2013). Furthermore, it is impossible to ensure that farmers are well guided in their various soil management practices without the use of relevant legislation and policies.

The conservation of natural resources is always associated with one form of legislation or policy and in some cases both, not just within the UK but globally. Such legislation and policies are quite often put in place to meet certain international, regional and national targets often in the form of treaties, directives and recommendations. This has led to the description of legislation and policies as an important tool in the conservation of natural resources (Hudson 1995). Such legislation and policies contribute to sustainable land management, forest and vegetation management, endangered species and their habitats, protection of agricultural land, and water and watershed management (Hannam 1999; cited in Stott et al. [eds.] 2001). Specific to soils, Hannam and Boer (2004) described legislation as a basic element necessary for the sustainability of soils and the principle aim of legislation for soils is to mitigate erosion, pollution, degradation and establish soil conservation institutions or authorities. At the international level various conventions and protocols have to some extent embraced the need for conservation of soil and their sustainable management. For example, the Brundtland report, "The World Commission on Environment and Development- Our Common Future" is well established for its sustainable development goals which has led to the development of various sustainable development policies, but it also contains some provision for soil conservation, with the recommendation that policies and legislation for soils should incorporate sustainable development objectives and future legislation should be significantly different from that in the past (Hannam and Boer 2002).

Despite legislation and programmes for soil conservation, soils are still subject to different forms of degradation (Ingram and Morris 2007; Boer and Hannam 2012; Vaneeckhaute et al. 2013). According to Hannam and Boer (2004), legislation and policies for soil conservation need to be built on two broad important principles, namely: ecological and scientific principles for sustainable soil use and the Resolution of the IUCN World Conservation Congress of 2000 on Sustainable Use of Soil. The conservation of soils in the UK, when compared to biodiversity and geodiversity over the past decades, has been described by Ingram and Morris (2007) as poor both in policy and industrial terms. They argued that even though the code for good agricultural practice for soil has been in place for over two decades, it is not enforcing and voluntary for farmers to practice it. According to Towers et al. (2005) the difficulty in assessing the nature conservation value of soils is the main challenge for the 
development of soil protection and conservation strategies. The situation is gradually improving as soil is beginning to make headlines in both conservation policies and programmes at the regional and national stage in view of climate change and food security concerns (Scottish Government 2009). In Europe and the UK obvious threats to agricultural soils has promoted the development of policies for their more sustainable management (Ingram 2008). In Europe, a thematic strategy for soil protection was adopted in 2006 with the primary aim of identifying the threats to soils and their protection among member states (EC 2006; SNIFFER 2008; Scottish Government 2009). The framework for the proposed EU Soil Directive which is still being debated was also introduced in the same year as a measure to minimize further degradation of European soils.

\section{AD Digestate and Soil Quality Improvement for Conservation}

The occurrence of digestate as an end by-product of the AD process makes AD unique and distinguishes it from other forms of renewable energy technologies. This digestate offers several benefits, mainly agricultural through soil improvement as well as research opportunities especially in the area of soil fertility improvement. Even though the full potential of the digestate in soil quality improvement is not fully understood, it is widely recognised as a rich organic fertilizer (Meester et al. 2012; Alburquerque et al. 2012a; Motte et al. 2013; Thomsen et al. 2013; Guercini et al. 2014). Some areas of research that have been explored on the use of digestate for agricultural purpose include but are not limited to digestate dry matter yield in relation to feedstock (Meester et al. 2012), digestate application as an amendment and fertilizer (Tambone et al. 2010), carbon dynamics and retention in soil after digestate application (Thomsen et al. 2013), relationship between digestate and carbon and nitrogen dynamics in amended soils (Alburquerque et al. 2012a), the effect of digestate on soil physical and mechanical properties (Beni et al. 2012) and the use of digestate for horticultural crop production and soil properties improvement (Alburquerque et al. 2012b). Digestate from AD can therefore improve soil quality in the following ways:

Organic matter addition- the organic nature of digestate implies addition of organic matter to soil when applied. The organic matter can improve water holding capacity of the soil, promote soil aggregate stability, increase soil cation exchange capacity, enhance soil microbial activity and minimize soil compaction. By improving soil aggregate stability and reducing soil compaction, soils are less prone to degradation by erosion. Beni et al. (2012) linked the improvement of soil physical properties to aggregate stability and porosity, and observed that digestate had a greater ability to do this than conventional inorganic fertilizers and compost.

Nutrient addition- like every other type of fertilizer, digestate from AD is capable of replenishing soil nutrients. Although the nutritional value of digestate varies significantly depending on the type of feedstock used for the digestion process (Wallace et al. 2011; Seadi and Lukehurst 2012; Thomsen et al. 2013), the digestate is very rich in organic carbon and nitrogen and values can range from 5.8 to 42.8 grams per litre $(\mathrm{g} / \mathrm{L})$ for total organic carbon (TOC) and 1.4 to $3.9 \mathrm{~g} / \mathrm{L}$ for total nitrogen $(\mathrm{TN})$ on fresh weight basis (Alburquerque et al. 2012a). Similarly, Thomsen et al. (2013) reported that carbon retention in soils treated with 
digestate account for $12-14 \%$ of carbon in feedstock. Table 1 shows the variation in nutrient content based on two main feedstock. The treatment, processing and storage of digestate also influence its nutrient content (Wallace et al. 2011; Seadi and Lukehurst 2012). Critics of digestate use for soil nutrient enrichment often base their arguments on the increased nitrogen and methane emissions it can cause, but a study by Meester et al. (2012) suggested that these emissions can be reduced by up to $50 \%$. Knowledge of the presence of other micro and macro nutrients in digestate is lacking and this has limited the wide use of digestate for arable crop production. However, the use of digestate for horticultural crop production like water melon has shown positive results on yield (Alburquerque et al. 2012b).

Table 1. Some nutrient contents in two types of whole digestate

Source: Wallace et al. (2011)

\begin{tabular}{|l|l|l|}
\hline Nutrients (kg per hectare) & Food-based digestate* & Manure-based digestate $* *$ \\
\hline Total N & 250 & 250 \\
\hline Readily Available N & 202 & 145 \\
\hline Total $\mathrm{P}_{2} \mathrm{O}_{5}$ & 16.3 & 77.0 \\
\hline Total $\mathrm{K}_{2} \mathrm{O}$ & 61.5 & 199 \\
\hline Total $\mathrm{MgO}$ & 2.04 & 42.2 \\
\hline Total $\mathrm{SO}_{3}$ & 15.0 & 73.0 \\
\hline
\end{tabular}

*applied at $34 \mathrm{~m}^{3} / \mathrm{ha}$

**applied at $57 \mathrm{~m}^{3} / \mathrm{ha}$

Soil conditioning- The AD process has a biomass yield of to $90 \%$ depending on the type of operation and feedstock (Messter et al. 2012), and this yield also contains significant amounts of fibre, which also varies with the system and feedstock. Astals et al. (2012) showed that digestate can contain up to $30 \mathrm{~g} / \mathrm{L}$ of fibre, and this fibre can be used to condition soil. The bulky nature of digestate in dried form means its addition to soils can improve resistance to compaction and also improve structure.

\section{Sustaining UK's Agriculture}

The ability of agriculture to continuously meet the needs of Man is in doubt in view of population growth, soil/land degradation, climate change, environmental pollution and urbanization. Forecasts for agricultural food production suggest that food production will have to increase by $70 \%$ to meet population demand by 2050 (Leaver 2011). As Man makes use of agriculture to meet his needs, over time; there has been a significant loss and damage to wildlife habitats and valued landscapes especially in rural areas (Ogaji 2005). Fowler (2010:1) described the scenario as "producing more food from less land, with lesser environmental impact". These concerns are not new in any sense, and form the basis of the concept of sustainable agriculture. However, the interpretation of the concept has been diverse both in theory and practice, thereby raising questions over its achievability in the world today. In fact, the agricultural systems in most developed nations were criticised for lacking 'sustainability' amidst levels of technological advancement (Hartridge and Pearce 2001). Sustainable agriculture has been described as agricultural production which utilizes natural resources in such a way that does not deplete the natural resources and still ensures safety for Humans and environment (Gruhn et al. 2000). A similar view was reported in FAO 
report (2002) defining sustainable agriculture as the successful management of agricultural resources to satisfy the needs Humans, and at the same time maintain and or enhance environmental quality and conserve natural resources for future generations. DFID (2004) gave two distinctive interpretations of sustainable agriculture. Firstly, sustainable agriculture based on the type of technology in a given setting especially those that focus on renewable inputs including permaculture, eco-agriculture, organic, community-based, farm-fresh, environmentally-sensitive, biodynamic and extensive strategies. The second interpretation, which is the main focus of this research, involves agricultural sustainability in term of resilience and persistence.

Sustainable agriculture covers three key elements, economic, social and environmental sustainability (Gruhn et al. 2000; DEFRA 2002). Economic sustainability here is concerned with the income of farmers and the general profitability of the agricultural production, under the basic assumption that for farmers to remain in business, the farming business needs to be viable and profitable. Social sustainability involves the general wellbeing of the farming community, their health, and access to basic amenities required for normal living. Environmental sustainability involves the reduction in the use of inorganic chemical inputs, pollution mitigation, low fossil fuel consumption, soil nutrient maintenance, sustained crop and animal diversity, on-farm energy production and conservation, community vitality and conservation tillage. These elements of sustainable agriculture, clearly illustrate the linkages with agriculture and the industrial sectors in modern agricultural systems, making use of an array of inputs which has made agriculture impact negatively on the environment (Ogaji 2005). Organic farming which is often misconstrued for sustainable agriculture refers to the farming practices that work in support of nature and not against, using those techniques that enhance crop yields without causing harm to the environment (HDRA 1998). It is therefore agricultural production that uses zero inorganic inputs in all aspects, and organic farming can thus be considered as part of sustainable agricultural practices.

In the UK, it is broadly believed that sustainable agriculture mainly involves an increase in the efficiency of resource use, like harnessing soil quality, minimising nitrogen loss, precision agriculture and a reduction in water use especially for irrigation (Farmers Weekly 2012). Even when the UK showed commitment to Agenda 21 of the Rio Conference by introducing its own strategy for sustainable development, that is, 'Sustainable Development: the UK strategy', the chapter of the report that dealt with agricultural sustainability was more focused on environmentally sensitive farming by setting out to achieve the following objectives as reported by Cobb et al. (1999):

a) provision of adequate good-quality food efficiently;

b) minimize the utilization of resources;

c) protect air, soil and water quality; and

d) preserve biodiversity and landscape quality.

By implication, economic and social sustainability are not really recognised, and just only a part of environmental sustainability is incorporated in this general consensus which has 
lingered for over two decades now, even though the UK has reported some tremendous success in organic farming in the last decade, coming $5^{\text {th }}$ in the production of certified organic foods globally (Harris et al. 2007; cited in Robinson [ed.] 2008). The situation has significantly halted the progress of sustainable agriculture within the UK, a situation even the government recognises. For instance, DEFRA (2002) reported in 'The Strategy for Sustainable Farming and Food-Facing the Future' that the UK was performing below expectations in the areas of social, economic and environmental elements of sustainable agriculture, and this is discussed as follows:

Social elements indicate that agriculture has affected tourism, job creation, income, and health of farmers in the UK. This shows the link between agriculture and other disciplines. The importance of interdisciplinary collaborations for achieving sustainable agriculture has also been identified by Harris et al. (2008). They stated that interdisciplinary linkages are fundamental to answering questions that arise in agro-ecosystems and land use research, and will also meet the needs of non-research stakeholders in sustainable agriculture.

Environmental elements showed that agriculture in the UK has led to more negative environmental impacts than benefits to the environment, costing £1-1.5 billion on the former and $£ 600-900 \mathrm{~m}$ for the latter per annum. Damages to the environment were mainly in the form of GHG emission, water pollution and damage to biodiversity. 90 per cent of some 10 tonnes of raw material used for production is discharged as waste, with packaging waste constituting 12 billion plastic bags and 29 billion drink and food cans. These figures support the call by Fowler (2010) for technology that will significantly reduce food production waste, and which will ultimately attract market all over the world.

Economic elements revealed that agriculture has not been very profitable, with a fall in the income of farmers the greatest since the 1930s. Overall food production is low at an estimated 20 per cent below world leaders in food production, and poor investment in capital. In the areas of food and drink industries for instance, workers had qualifications 20-30 per cent lower than elsewhere in Europe and Japan.

On the side of farmers in the UK, Robinson (2008) noted that the challenge of measuring the gain and losses to natural resources has limited sustainable agricultural practices, and that farmers are more concerned with the economic component of sustainable agriculture, with very little consideration for the environment. This paper goes on to stress and question; how much do farmers actually know about their soil and land resource? It is expected that only very little is known just as Ingram (2008) reported, and more so, it will be difficult for farmers to fully acknowledge the need to conserve their soil and land resources if they know little about it. Raising awareness of farmers on the importance of their soil and land resources beyond the economic benefit and gains is necessary for reorientation of farmer's perception. The use of soil trails is an effective way of informing people about soils and land resources to encourage their conservation and has been promoted by Burek (2005) and Conway (2010).

\section{Sustainable Development- The Nexus of AD, Soil Conservation and Sustainable}

\section{Agriculture}




\section{Macrothink

The concept have been uneven over the years, and have been judged to be the main inherent challenge to sustainable development (Robinson 2008). More recently, researchers and policy makers tend to include a fourth indicator known as an institutional indicator (Ivanovic et al. 2009). Among the basic of sustainable development traditionally had three indicators namely: economic, ecological and social indicators (Barrow 2006; Robinson 2008). Priorities on these three indicators of sustainable development, Barrow (2006) stated that the ecological indicator mainly concerned with environmental protection is the main propellant of the theory of sustainable development in the $21^{\text {st }}$ century. Achieving sustainable development through such a reliable and viable technology as $\mathrm{AD}$, in addition to soil conservation and sustainable agriculture in a rural setting is the main message of this article and this is illustrated in Figure 2 .

From an economic indicator point of view, sustainable development is concerned with employment, increased income, poverty reduction, return on investment (profit), reduction in inequality, enhanced production and energy efficiency and access to credit facilities (Mog 2004). It is argued that with anaerobic digestion technology which has the potential of generating income as earlier discussed, poverty will be reduced, energy use will be more efficient, agricultural production can be enhanced, to a reasonable extent employment will be created. Also the use of digestate from AD plants can help minimise cost for farmers by utilising their own resources (Seadi and Lukehurst 2012). This is represented as overlap 6 in Figure 2, where AD interacts with sustainable agriculture.

Social indicators of sustainable development include education, health, housing, gender equality, population statistics and rate of growth. In a rural perspective, anaerobic digestion technology, sustainable agriculture and the conservation of soils can aid the desired figures of the aforementioned parameters. Anaerobic digestion can create employment and provide income as already discussed. From a sustainable agriculture and soil conservation point of view, the use of digestate on soil can promote clean water supply, healthier food using zero inorganic inputs, and minimize the spread of harmful pathogens when the digestate is properly treated (Seadi and Lukehurst 2012). This interaction is represented as overlaps 4, 5 and 6 in Figure 2. 


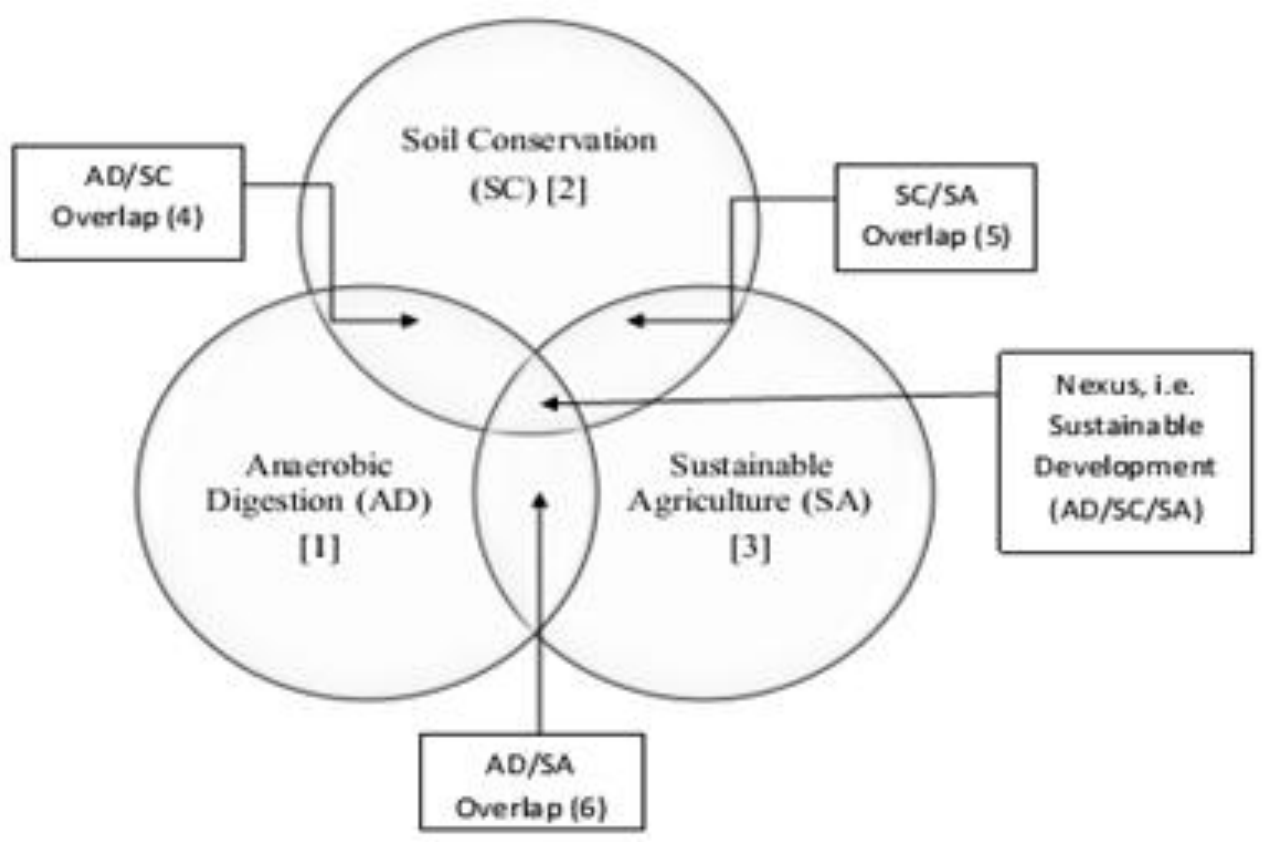

Figure 2. Nexus of AD, soil conservation and sustainable agriculture and their overlaps

Environmental indicators include the minimization of soil and land degradation, minimization of air, land and water pollution, protection of biodiversity and geodiversity and the overall retention of ecological integrity according to Mog (2004) are direct benefits of AD technology, soil conservation and sustainable agriculture. This is represent in Figure 2 as overlap 4 and 6 which is the interaction of $\mathrm{AD}$ with soil conservation and sustainable agriculture respectively. With respect to the digestate quality, compliance to specific environmental standards is ensured by the British Standards Institution (BSI). The specification for biofertilisers is the PAS 110, otherwise known as the Biofertiliser Certification Scheme (ADBA 2013). This stipulates the suitability of inputs and how they are processed by $\mathrm{AD}$; and the market standards for environmental protection.

Last but not least, institutional indicators, which are not always included in most interpretations of the concept, are quite applicable to this study. For instance, Ivanovic et al. (2009) identified technological advancement as an indicator of institutional sustainable development, and AD technology is a good example of technological advancement in the area of waste recycling and renewable energy generation. Also, technological advancement is crucial to achieving economic growth and thereby promotes sustainable development.

\section{AD Technology in the UK}

Renewable energy technologies represent one of those areas of research geared towards achieving sustainable development mainly through environmental protection and economic sustainability of the practise. The need for AD technologies in our society today is further justified by the enormous amounts of biodegradable wastes produced from agricultural systems; mainly livestock systems and the risk posed to the environment if such wastes are not well managed (Alburquerque et al. 2012a). Although AD technology has long been 
identified as a method of energy production in the form of biogas (Banks et al. 2008; Meester et al. 2012; Guercini et al. 2014) its promotion and adoption has often been linked to environmental protection targets and objectives at international and national levels (Zglobiz et al. 2010; Tranter et al. 2011; Guercini et al. 2014). For instance, the European Union is committed to a $20 \%$ decrease in greenhouse gas emissions by the year 2020 and renewable energy technologies remain instrumental in achieving such goals.

The agricultural sector represents one of the key aspects of the UK economy and its influence on the environment has long been studied. Levels of organic waste production on UK farms are large and therefore make their renewal an important source of energy production in the light of sustainable development goals (Zglobiz et al. 2010). Bio-wastes used as raw materials in the $\mathrm{AD}$ process are adequate in the $\mathrm{UK}$ and their quantity has risen over the years. For instance, Dagnall (1995) reported that a total of 14 million tonnes of livestock slurry were produced in the UK each year. At that time, AD experience in the UK was poor, mainly due to low biogas yield as a result of inadequate total dry solid in feedstock (Dagnall 1995). These figures have risen significantly and recent estimates indicate that a total of 90 to 100 million tonnes of slurry (all livestock included) are produced annually in the UK (Bywater 2011). This increase in biodegradable waste from UK farms shows that the agricultural sector has grown over the years, increasing the need for enhanced waste management because the environment is faced with greater risks now than in the past. More so, DEFRA (2011) reported that some 16 million tonnes of post-farm food and drink waste arises each year in the UK. Despite these increases, the number of AD plant in the UK remains low when compared to organic waste outputs and these have been linked to a number of challenges (Bywater 2011).

UK is also one of those countries within the EU committed to the union's environmental goals and objectives through its various legislation and policies that aim to encourage renewable energy and environmental protection (Zglobiz et al. 2010; POST 2011). These types of policies and legislation have been instrumental in the promotion of AD technology within the UK (Zglobiz et al. 2010) and other parts of Europe (Wilkinson 2011). The level of commitment of these polices with regard to stated targets remains questioned and so is the issue of feasibility of the targets (Zglobiz et al. 2010). Recent policies however tend to utilise incentives as a means of motivating farmers and investors alike to engage in renewable technologies such as AD (POST 2011). It is also important to stress at this point that the promotion of $\mathrm{AD}$ has not strictly been the sole responsibility of the UK government, and various organisation and bodies within the UK have been actively involved. For example, DEFRA's target of 1000 AD plants by 2020 has been largely promoted by the Royal Agricultural Society of England (RASE) funded mainly by charity organisations like Frank Parkinson Agricultural Trust (Bywater 2011). As of June 2012, there were a total of 78 AD plants in operation in the whole of UK, making use of waste feedstock and treating farm feedstock (DEFRA 2012).

Prime among the challenges of $\mathrm{AD}$ technology in the UK is the issue of siting an AD plant. Dagnall (1995) stated that AD plants are best located close to required input resource such as feedstock, which will ensure attractive economics of scale. The, availability of market for the 
energy generated is also an important issue that affects the location of AD plants (Allen Kani Associates and Enviro RIS Ltd. 2001; Bywater 2011). Just like availability for energy utilisation, it is also important that AD plants are sited in proximity to an available market for the digestate produced. Another very important issue that affects the siting of AD plants is community acceptability. Khan (2002; cited in Boholm and Löfstedt (Eds.) 2005 ) stated that, government bodies, corporate organisations, the general public and private individuals tend to welcome the idea of renewable technologies as a form of sustainable development, but their acceptability of renewable energy projects in terms of location is often controversial. Such controversies can effectively hinder the development of AD plants. In the UK, there is a well-defined procedure for the development of $\mathrm{AD}$ plants that is aimed at minimising conflicts of interest and ensuring human and environmental safety (SWEA 2011).

Cost implications for the establishment of AD plants and the professional advice process are thought to be significant challenges to its widespread adoption, and in most cases, developers and investors are unaware of the funding available (DEFRA 2011). This problem of cost is also well established in the minds of farmers as a recent study conducted by Tranter et al. (2011) on the adoption of AD in England revealed that $93.4 \%$ of survey respondents considered the cost of establishing an AD plant as being too high. It is estimated that the capital cost for an average AD plant of up to $300 \mathrm{~kW}$ is over $£ 700,000$ (Yeatman 2006), and this clearly shows that the technology is far beyond the financial capacity of most famers within the UK. Various incentives and opportunities are in place to encourage investment by farmers and other stakeholders in the technology, yet again, the issue of type and scale of such incentives represent another basis for debate on the technology.

Another challenge to AD in the UK is the legislation and regulations that guide and monitor $\mathrm{AD}$ developments and planning. Over the years, a range of legislation and a variety of regulations have affected $\mathrm{AD}$ and these have been interpreted and applied in different ways in the development of AD projects (Bywater 2011). For the various types of feedstock, residues (digestate) quality, the different digestion capacity and the energy yield in terms of biogas, there are specific regulations and standards to be met (DEFRA 2011). Although such regulations are important for the effective management of the renewable energy sector, the regulations themselves can be a barrier to the development of the sector (Wilkinson 2011). The complexity of regulations and policies for AD development according to Bywater (2011) is more pronounced because $\mathrm{AD}$ technology spans a number of disciplines thus involving more regulatory bodies such as European legislation, the Environment Agency, DEFRA, Animal Health, DECC and local planning authorities. The ideal policy and regulatory guide should promote the use of the technology with incentives that will support small, medium and large scale plants for the overall goal of boosting UK energy and the sustainable development portfolio. Another suggestion made by Zglobisz et al. (2010) is that policy and regulations should acknowledge the localised nature of $\mathrm{AD}$ as a renewable energy option and remain rigidly structured. Gap analysis of AD in the UK shows that, these suggestions are being considered by DEFRA as contained in the reports of Frith and Gilberth (2011).

Access to funds in the form of capital grants is another challenge for farmers in the UK. The problem is more dominant with small and medium scale commercial farmers that often 
require the financing of slurry tanks (Bywater 2011). The problem is further compounded by the relatively low awareness of the importance of small AD plants and their place in the UK energy portfolio (Zglobisz et al. 2010; Bywater 2011). In the past, around the late 1980s and 1990 s, AD plant owners took advantage of the pollution abatement award which was between 30\%-60\% and this initiative supported approximately 30 digesters (Bywater 2011). More recently there are more incentives in place to support farmers and prospective investors interested in AD plants, but access to these incentives remains a challenge. The incentives are even more focused on existing plant owners rather than prospective owners. There are four financial incentives currently in place for $\mathrm{AD}$ development in the UK.

a) Feed in Tariffs (FiTs);

b) Renewable Obligation Certificates (ROCs);

c) Renewable Heat Incentive (RHI); and

d) Renewable Transport Fuel Obligation (RTFO).

FiTs, an initiative by the UK government to encourage renewable energy requires that an installation for renewable energy exists and has a certain level of energy generation capacity before the licence can be awarded. The main aim of this incentive is to promote the use of electricity from small-scale renewable generation. The tariff is categorised into different bands in accordance to generation capacity of the plant as shown in Table 2. The rates in Table 2. are guaranteed for twenty years for agreed contracts but are subject to increase with inflation each year (Ofgem 2013). In the case of surplus electricity generation and onward export to the wider distribution network there is a guaranteed minimum export tariff of $4.64 \mathrm{p} / \mathrm{kWh}$ can be paid or the energy supplier can negotiate a price. However, the survey carried out by Bywater (2011) shows that the current FiTs levels are too low to make AD attractive.

Table 2. FiT rates for projects approved before 31st March 2014

Source: Ofgem (2013)

\begin{tabular}{|l|l|}
\hline $\begin{array}{l}\text { Total generating capacity } \\
\text { (kW) }\end{array}$ & Rate $(\mathrm{p} / \mathrm{kWh})$ \\
\hline 0 to 250 & 15.16 \\
\hline$>250$ to 500 & 14.02 \\
\hline$>500$ & 9.24 \\
\hline
\end{tabular}

ROCs are certificates awarded to eligible renewable electricity suppliers who meet certain annual obligations, and who must use renewable, or contract renewable energy from outside generators (Juniper 2007, Ofgem 2011). These certificates can be traded and as such the subsidy provided to renewable energy generation installations is not fixed unlike the case of FiTs.

RHI is another financial support mechanism to encourage the production of heat, and is very similar to FiTs in the sense that the subsidy is provided on a per $\mathrm{kWh}$ basis as shown in Table 3. DECC (2011) described the RHI as an initiative aimed at reducing carbon emissions in the 
UK. It is however important to state that only heat used for a specific purpose attracts the subsidy.

Table 3. RHI rates as of April 2013

Source: REA (2013)

\begin{tabular}{|l|l|}
\hline $\begin{array}{l}\text { Total generating capacity } \\
\text { (kW) }\end{array}$ & Rate $(\mathrm{p} / \mathrm{kWh})$ \\
\hline 0 to 200 & 7.1 \\
\hline
\end{tabular}

RTFO is a subsidy geared towards the use of renewable fuels in transportation. It allows for upgrade of biogas as a transport fuel and this is often associated with some fixed costs making the RTFO unsuitable for small-scale AD plants or other small-scale renewable energy generation (REA 2013).

\section{Conclusion}

Concerns on food security issues, rising world population, climate change, environmental degradation and sustainable development goals calls for serious attention in this $21^{\text {st }}$ century. One of those areas demanding attention is alternative renewable technologies for sustainable energy generation, waste recycling and environmental protection. This review has shown the benefits of $\mathrm{AD}$ in terms of energy generation from organic waste, waste recycling, income generation and soil quality improvement. These benefits have been linked to soil conservation and sustainable agricultural development. It also showed the need to conserve soil and sustainable agriculture as an international and national issue. Earlier, Duruiheoma et al. (2014) identified various options and challenges to raising awareness for AD in the UK as well as possible solutions to the challenges. The lapses in terms of policy and legislation for $\mathrm{AD}$, incentives for renewable energy production and access to capital funds for $\mathrm{AD}$ development need to be improved. In the area of agricultural application of digestate from AD through soil quality improvement, there is need for further research into the fertility potentials of digestate to extend its use to arable crops production. The urgency and importance of AD technology are also supported by the rise in energy demand emanating from population growth, the amount of agricultural waste produced in the UK, GHG emission targets and the need to achieve sustainable development.

\section{References}

ADBA (2013). The practical guide to AD ( $1^{\text {st }}$ edition). Digestate, Chapter 6. London: ADBA. Alburquerque, J. A, Fuente, C., \& Bernal, M. P. (2012a). Chemical properties of anaerobic digestates affecting $\mathrm{C}$ and $\mathrm{N}$ dynamics in amended soils. Agriculture, Ecosystems and Environment, 160, 15-22.

Alburquerque, J. A., Fuente, C., Campoy, M., Carrasco, L., Najera, I., Baixauli, C., Caravaca, F., Roldan, A., Cegarra, J., \& Bernal, M. P. (2012b). Agricultural use of digestate for horticultural crop production and improvement of soil properties. European Journal of Agronomy, 43, 119-128. 
Allen Kani Associates \& Enviros RIS Ltd (2001) Implications of Different Waste Feed Streams (Source-Separated Organic and Mixed Waste) on Collection Options and Anaerobic Digestion Processing Facility Design, Equipment and Costs. WDO Study, December 2001. [Online] Available: http://www.nerc.org/documents/toronto_report.pdf (Accessed 20 June 2013)

Astals, S., Nolla-Ardevol, V., \& Mata-Alvarez, J. (2012). Anaerobic co-digestion of pig manure and crude glycerol at mesophilic conditions: Biogas and Digestate. Bioresource Technology, 110, 63-70.

Banks, C., Chesshire, M., \& Stringfellow, A., (2008). A pilot-scale comparison of mesophilic and thermophilic digestion of source segregated domestic food waste. Water Science and Technology, 58, 1475-1481.

Barrow, C. J. (2006). Environmental Management for Sustainable Development (2nd ed.). London: Routeledge.

Beni, C., Servadio, P., Marconi, S., Neri, U., Aromolo, R., \& Diana, G. (2012). Anaerobic Digestate Administration: Effect on Soil Physical and Mechanical Behavior. Communications in Soil Science and Pant Analysis, 43, 821-834. http://dx.doi.org/10.1080/00103624.2012.648359

Blanco-Canqui, H., \& Lal, R. (2009). Crop Residue Removal Impacts on Soil Productivity and Environmental Quality. Critical Review in Plant Science, 28, 139-163. http://dx.doi.org/10.1080/07352680902776507

Bo, L., Ting-xin, D., Zhi-ping, L., Lou-wei, M., Zhu-xuen, W., \& An-xiu, M. (1993). Use of night soil in agriculture and fish farming. World Health Forum, 14, 67-70.

Boardman, J., Poesen, J., \& Evans, R. (2003). Socio-economic factors is soil erosion and conservation. Environmental Science \& Policy, 6, 1-6.

Brady, N. C., \& Weil, R. R. (2005). The Nature and Properties of Soils (13th ed.). India: Pearson Education.

Burek, C. V. (2005). England's first soil trail. Earth Heritage, 24, 12.

Bywater, A. (2011). A Review of Anaerobic Digestion Plants on UK Farms- Barriers, Benefits and Case Studies A report prepared with financial support from the Frank Parkinson Agricultural trust. Warwickshire: RASE

Cobb, D., Dolman, P., \& O'Riordan, T. (1999) Interpretations of sustainable agriculture in the UK. Progress in Human Geography, 23(2), 209-235.

Conway, J. S. (2010). A Soil Trail?- A Case Study from Anglesey, Wales, UK. Geoheritage, 2, $15-24$.

Dagnall, S. (1995). UK Strategy for Centralised Anaerobic Digestion. Bioresource Technology, 52, 275-280. 
DEFRA: Department for Environment, Food and Rural Affairs (2002). The Strategy for Sustainable Farming and Food-Facing the Future. London: DEFRA. [Online] Available: http://archive.defra.gov.uk/foodfarm/policy/sustainfarmfood/documents/sffs.pdf (Accessed 5June 2012)

DEFRA: Department for Environment, Food and Rural Affairs (2011). Anaerobic Digestion Strategy and Action Plan- A commitment to increasing energy from waste through Anaerobic Digestion. London: [Online] DEFRA. Available: https://www.gov.uk/government/uploads/system/uploads/attachment_data/file/69400/anaerob ic-digestion-strat-action-plan.pdf . (Accessed 25 May 2012)

DEFRA: Department for Environment, Food and Rural Affairs (2012). Anaerobic Digestion Strategy and Action Plan- Annual Report on Progress 2011/2012, July 2012. London: DEFRA. [Online] Available: https://www.gov.uk/government/uploads/system/uploads/attachment_data/file/69566/pb1378 8-ad-2012-progress.pdf (Accessed 20 February 2013)

DFID: Department for International Development (2004). Agricultural Sustainability. London: DFID. [Online] Available: http://dfid-agriculture-consultation.nri.org/summaries/wp12.pdf (Accessed 25 April 2013)

Duruiheoma, F. I., Burek, C., Bonwick, G., \& Alexander, R. (2014). Raising Awareness of Anaerobic Digestion in the UK- Views of Key Stakeholders. Journal of Environment and Ecology, 5(2), 258-275.

EC: European Commission (2006). The Thematic Strategy for Soil Protection. Communication from the commission to the council, the European Parliament, The European Economic and Social Committee and The Committee of The Regions. Brussels: EC.

El-Swaify, S. A. (1994). State of the art for assessing soil and water conservation needs and technologies. In Morgan, R. P. C. (3rd ed.), Soil Erosion and Conservation. Oxford: Blackwell publishing.

FAO: Food and Agriculture Organization (2002). Soil Biodiversity and Sustainable Agriculture. Paper prepared as a background paper for the Ninth regular Session of the Commission on Genetic Resources for Food and Agriculture (CGRFA) FAO-Rome, 14-18 October 2002. Rome: FAO. [Online] Available: http://www.fao.org/fileadmin/templates/nr/images/resources/pdf_documents/CGRFA_SoilBi odSustAg.doc (Accessed 13 August2012)

Farmers Weekly. (2012). What is sustainable agriculture? Rural Living Articles, Monday 16 April 2012 (Online Resource) [Online] Available: http://www.fwi.co.uk/articles/16/04/2012/132441/what-is-sustainable-agriculture.htm\#.UdAh BP14LWg

Fowler, C. (2010). Conserving Diversity: The Challenge. Global Crop Diversity Trust, Rome: FAO. 
Frith, P., \& Gilbert, J. (2011). Anaerobic Digestion Evidence Availability and Gap Analysis Report to Defra, project number WR1311.

Golusin, M., Ivanovic, O. M., \& Teodorovic, N. (2011). The review of the achieved degree of sustainable development in South Eastern Europe- The use of linear regression method. Renewable and Sustainable Energy Reviews, 15, 766-772.

Gordon, J. E., Gubbins, N., Taylor, A. G., \& McKirdy, A. P. (1995). Soils and Sustainability: A Natural Heritage Perspective. In Taylor, A. G., Gordon, J. E., \& Usher, M. B. (Eds.), Soils, sustainability and the Natural Heritage. Scottish Natural Heritage, Edinburgh: HMSO

Gruhn, P., Goletti, F., \& Yudelman, M. (2000). Integrated nutrient management, soil fertility and sustainable agriculture: current issues and future challenges. Food, Agriculture and the Environment Discussion paper, 32, Washington: International Food Policy Research Institute

Guercini, S., Castelli, G., \& Rumor, C. (2014). Vacuum evaporation treatment of digestate: Full exploitation of cogeneration heat to process the whole digestate production. Water Science and Technology: A Journal of the International Association on Water Pollution Research, 70(3), 479

Hannam, I. (1999). Ecologically Sustainable Soil: The Role of Environmental Policy and Legislation. In Stott, D. E., Mohtar, R. H., \& Steinhardt, G. C. (Eds.), Sustaining the Global Farm. Selected papers from the $10^{\text {th }}$ International Soil Conservation Organization Meeting held May 24-29, 1999 at Purdue University and the USDA ARS National Soil Erosion Research Laboratory.

Hannam, I., \& Boer, B. (2002). Legal and Institutional Frameworks for Sustainable Soils: A Preliminary Report. Gland, Switzerland and Cambridge, UK: IUCN. xvi + 88 pp.

Hannam, I., \& Boer, B. (2004). Drafting Legislation for Sustainable Soils: A Guide. Gland, Switzerland and Cambridge, UK: IUCN. x + 100 pp.

Hannam, I., \& Boer, B. (2012). RIO+20: What Ambition for the Environment? A Background Paper for World Conservation Congress IUCN commission on Environmental Law Workshop on a Soil Convention, 6 September 2012- Third Worldwide Conference of Environmental Law NGO and Lawyers. Gland, Switzerland and Cambridge, UK: IUCN. [Online] Available: https://portals.iucn.org/2012forum/sites/2012forum/files/paper-soil-protocol-cidce-limoges-ri o-20-symposium-final-25-august-2011-1.pdf (Accessed 10 July 2013)

Harris, F., Lyon, F., \& Clarke, S. (2008). Doing interdisciplinary: motivation and collaboration in research for sustainable agriculture in the UK. Area, 41(4), 374-384.

Harris, F., Robinson, G. M., \& Griffiths, I. (2007). A Study of the Motivations and Influences on Farmers' Decisions to leave Organic Farming Sector in the United Kingdom, In: Robinson, G. M. (ed.) (2008) Sustainable Rural Systems: Sustainable Agriculture and Rural Communities- perspective on rural policy and planning, Ashgate publishing.

Hartemink, A., \& van Keulen, H. (Eds.) (2005) Soil degradation in Sub-Saharan Africa; cited in: Ingram, J. and Morris, C. (2007) The knowledge challenge within the transition towards 
sustainable soil management: An analysis of agricultural advisors in England. Land Use Policy, 24, 100-117.

Hartridge, O., \& Pearce, D. (2001). Is UK Agriculture Sustainable? Environmentally Adjusted Economic Accounts for UK Agriculture. CSERGE-Economics, University College London. [Online] Available: http://www.cserge.ucl.ac.uk/AGNNP.FINALFINAL.pdf ((Accessed 5 April 2013).

HDRA: Henry Doubleday Research Association (1998). What is Organic Farming? Coventry: HDRA. [Online] Available: http://www.infonet-biovision.org/res/res/files/488.OrgFarm.pdf (Accessed 27 May 2013)

Hollister, E. B., Forrest, A. K., Wilkinson, H. H., Ebbole, D. J., Tringe, S. G., Malfatti, S. A., Holtzapple, M. T., \& Gentry, T. J. (2012). Mesophilic and The mophilic Conditions Select for Unique but Highly Parallel Microbial Communities to Perform Carboxylate Platform Biomass Conversion. PLoS ONE 7(6): e39689. doi:10.1371/journal.pone.0039689

Hudson, N. (1995). Soil Conservation (3rd ed). Ames: Iowa State University Press

Ingram, J. (2008). Are farmers in England equipped to meet the knowledge challenge of sustainable soil management? An analysis of farmer and advisor views. Journal of Environmental Management, 86, 214-228.

Ingram, J., \& Morris, C. (2007). The knowledge challenge within the transition towards sustainable soil management: An analysis of agricultural advisors in England. Land Use Policy, 24, 100-117.

Ivanovic, O. D. M., Golusin, M. T., Dodic, S. N. \& Dodic, J. M. (2009). Perspectives of sustainable development in countries of Southeastern Europe, Renewable and Sustainable Energy Review, 13, 2079-2087.

Johansen, A., Carter, M. S., Jensen, E. S., Hauggard-Nielsen, H.. \& Ambus, P. (2013) Effects of digestate from anaerobically digested cattle slurry and plant materials on soil microbial community and emission of $\mathrm{CO}_{2}$ and $\mathrm{N}_{2} \mathrm{O}$. Applied Soil Ecology, 63, 36-44.

Juniper (2007). Commercial Assessment Anaerobic Digestion Technology for Biomass Projects. Prepared by Juniper for Renewable East, BIOREGEN, Juniper Consultancy Services Ltd June [Online] Available: http://www.biomassenergycentre.org.uk/pls/portal/docs/PAGE/RESOURCES/REF_LIB_RES /PUBLICATIONS/GUIDANCE/RENEWABLES\%20EAST\%20-\%20ANAEROBIC\%20DIG ESTION\%20(FULL\%20REPORT).PDF (Accessed 15 July 2013)

Khan, J. (2002). Siting conflicts in renewable energy projects: A biogas case study, cited in; $\AA$. Boholm and R. Löfstedt (Eds.) (2005) Facility Siting: Risk, Power and Identity in Land-Use Planning, London: Earthscan

Khanif, Y. M. (2010). Improvement of soil carrying capacity for better living. J. ISSAAS, 16(1), 1-7. 
Lawson, T. (2010). Overview of Anaerobic Digestion and Digesters. North East Biogas; Clean Energy for Life. New York: Environmental Protection Agency (EPA). [Online] Available: http://www.epa.gov/region2/webinars/pdfs/3-24-10_1.pdf

Leaver, J. D. (2011). Global food supply: a challenge for sustainable agriculture. Nutrition Bulletin, 36, 416-461.

Lei, B., \& Haight, M. (2007). Anaerobic Digestion and Community Development: A Case Study from Hainan Province, China. Environmental Development Sustainability, 9, 501-921.

Lucas, F. S., Therial, C., Gonclaves, A., Servais, P., Rocher, V., \& Mouchel, J. M. (2014). Variation of raw wastewater microbiological quality in dry and wet weather conditions. Environ Sci Pollut Res Int., 21(8), 5318-28.

Mainero, D. (2012). Integrated anaerobic-aerobic systems for solid waste treatment. Rev Environ Sci Biotechnol, 11, 343-352. http://dx.doi.org/10.1007/s11157-012-9300-0

Mcolivers, J. U. (1984). Productivity of arable lands associated with contamination of crude oil. American Society of Agronomy, Madison WL, 89-113.

Meester, S., Demeyer, J., Velghe, F., Peene, A., Langenhove, H., \& Dewulf, J. (2012). The environmental sustainability of anaerobic digestion as a biomass valorization technology. Bioresource Technology, 121, 396-403.

Mog, J. M. (2004). Struggling with Sustainability- A comparative Framework for Evaluating Sustainable Development Programs. World Development, 32(12), 2139-2160.

Morgan, R. P. C. (2005). Soil Erosion and Conservation (3rd ed.). Oxford: Blackwell publishing.

Motte, J, Trably, E., Escudie, R., Hamelin, J., Steyer, J., Bernet, N., Delgenes, J., \& Dumas, C. (2013). Total solids content: A key parameter of metabolic pathways in dry anaerobic digestion. Biotechnology for Biofuels, 6, 164.

Ofgem (2011). Renewables Obligation: Guidance for generators. Ofgem E-Serve, May 2011. London: Ofgem. [Online] Available: https://www.ofgem.gov.uk/ofgem-publications/58150/ro-generator-guidance-may-2011-final. pdf (Accessed 20 July 2013)

Ofgem (2013). Feed-in Tariff Payment Rate Table for Non-Photovoltaic Eligible Installations for FIT Year 4 (1 April 2013 to 31 March 2014). Ofgem E-Serve. London: Ofgem. [Online] Available:

https://www.ofgem.gov.uk/ofgem-publications/58940/fit-tariff-table-1-april-2013-non-pv-onl y.pdf (Accessed 20 July 2013)

Ogaji, J. (2005). Sustainable Agriculture in The UK. Environment, Development and Sustainability, 7, 253-270.

POST: Parliamentary Office of Science and Technology (2006). UK Soil Degradation. 
Postnote, No. 265, London: POST.

POST: Parliamentary Office of Science and Technology (2011). Anaerobic Digestion. Postnote, No. 387, London: POST.

REA Biogas: Renewable Energy Association Biogas (2013). Increasing Deployment of Small-Scale, On-farm Anaerobic Digestion Plants. Small scale AD Roundtable Background paper, April 29, 2013. London: REA. [Online] Available: http://www.biogas.org.uk/images/upload/events_51_Small-scale-AD-Roundtable-background -paper-v4-1.pdf (Accessed 22 August 2013)

Robinson, G. M. (2008). Sustainable Rural Systems: An Introduction, In: Robinson, G. M. (ed.) Sustainable Rural Systems: Sustainable Agriculture and Rural Communitiesperspective on rural policy and planning, Ashgate publishing.

Rogers, P. P., Jalal, K. F., \& Boyd, J. A. (2008). An Introduction to Sustainable development. UK and USA: Earthscan

Rowell, D. M., Prescott, C. E., \& Preston, C. M. (2001). Decomposition and nitrogen. In Tambone, F., Scaglia, B., D’Imporzano, G., Schievano, A., Orzi, V., \& Adani, S. F. (2010) Assessing amendment and fertilizing properties of digestates from anaerobic digestion through a comparative study with digest sludge and compost. Chemosphere, 81, 577-583.

Saedi, T., \& Lukehurst, C. (2012). Quality management of digestate from biogas plants used as fertiliser. IEA Bioenergy: Task 37-Enrgy from Biogas.

Satihal, D. G., Vaikunthe, L. D., \& Bhargava, P. K. (2007). Impact of Population Growth on Agricultural Land Utilization in Karnataka, India. Princeton Papers. [Online] Available: http://uaps2007.princeton.edu/papers/70762 . (Accessed 30 June 2013)

Schloter, M., Dilly, O., \& Munch, J. C. (2003). Indicators for evaluating soil quality. Agriculture, Ecosystems and Environment, 98, 255-262.

Scottish Government. (2009). The Scottish Soil Framework. Edinburgh: Scottish Government. [Online] Available: http://www.scotland.gov.uk/Resource/Doc/273170/0081576.pdf (Accessed 3 August 2012)

SNIFFER (2008). Strategic Environmental Assessment DRAFT- Practical Guidance for Practitioners on How to Take Account of Soil, SECTION 2- SOIL, Edinburgh: SNIFFER.

SWEA: Severn Wye Energy Agency (2011). Country Specific Conditions and Barriers to Implementation for Anaerobic Digestion Plants in England and Wales. Promotion of bio-methane and its market development through local and regional partnerships, A project under the Intelligent Energy- Europe programme. [Online] Available: http://www.swea.co.uk/Bio-methaneRegions/downloads/framework_EW.pdf (Accessed 20 July 2013)

Tambone, F., Scaglia, B., D’Imporzano, G., Schievano, A., Orzi, V., \& Adani, S. F. (2010). Assessing amendment and fertilizing properties of digestates from anaerobic digestion through a comparative study with digest sludge and compost. Chemosphere, 81, 577-583. 


\section{Macrothink}

Thomsen, I. K., Olesen, J. E., Moller, H. B., Sorensen, P., \& Christensen, B. T. (2013). Carbon dynamics and retention in soil after anaerobic digestion of dairy cattle feed and faeces. Soil Biology \& Biochemistry, 58, 82-87.

Towers, W., Malcolm, A., \& Bruneau, P.M.C (2005). Assessing the nature conservation value of soil and its relation with designated features, Scottish Natural Heritage Commissioned Report No. 111 (ROAME No. F03AC104). (Accessed 3 August 2012)

Tranter, R. B., Swinbank, A., Jones, P. J., Banks, C. J., \& Salter, A. M. (2011). Assessing the potential for the uptake of on-farm anaerobic digestion for energy production in England, Energy Policy, 39, 2424-2430.

Uri, N. D., \& Lewis, J. A. (1998). The dynamics of soil erosion in US agriculture, In: Morgan, R. P. C. (2005) Soil Erosion and Conservation, $3^{\text {rd }}$ edition, Oxford: Blackwell publishing.

Vaneeckhaute, C., Meers, E., Michels, E., Buysse, J., \& Tack, F.M.G. (2013). Ecological and economic benefits of the application of bio-based mineral fertilizers in modern agriculture. Biomass and Bioenergy, 49, 239-248.

Wallace, P., Frederickson, J., Chambers, B., Taylor, M., Longhurst, P., Tyrrell, S., Gale, P., Goddard, A., \& Litterick, A. (2011). Digestates: Realising the fertiliser benefits for crops and grassland. Guidance document: Wrap (Cymru).

WCED: World Commission on Environment and Development (1987). Our Common Future. Brundtland report. Oxford: Oxford University Press for WCED.

Wilkinson, K. G. (2011). A comparison of the drivers influencing adoption of on-farm anaerobic in Germany and Australia Biomass and Bioenergy, 35, 1613-1622.

Wood, B. M., Jader, L. R., Schendel, F. J., Hahn, N. J., Valentas, K. J., McNamara, P. J., Novak, P. M., \& Heilmann, S. M. (2013). Industrial symbiosis: Corn ethanol fermentation, hydrothermal carbonization, and anaerobic digestion. Biotechnology and Bioengineering, 110(10), 2624-2632. http://dx.doi.org/10.1002/bit.24924

Yeatman, C. O. (2006). The Profitable use of Anaerobic Digestion (AD) on UK Farms. A 2005/2006 Nuffield Farming Scholarship Study. [Online] Available: http://www.nuffieldinternational.org/rep_pdf/1226661015Yeatman,_Owen.pdf (Accessed 27 May 2013)

Zglobisz, N., Castillo-Castillo, A., Grimes, S., \& Jones, P. (2010). Influence of UK energy policy on the deployment of anaerobic digestion. Energy Policy, 38, 5988-5999.

\section{Copyright Disclaimer}

Copyright for this article is retained by the author(s), with first publication rights granted to the journal.

This is an open-access article distributed under the terms and conditions of the Creative Commons Attribution license (http://creativecommons.org/licenses/by/3.0/). 